\title{
Project Title: $\quad$ Isotopic Tracers for Waste Fluid Tracking and Fluid-Soil Interactions: Hanford, Washington
}

Project Number: $\mathbf{7 3 7 7 3}$

\section{Lead PI: $\quad$ Dr. Donald J. DePaolo, Lawrence Berkeley National Laboratory}

\section{Research Objective}

The objective of this research is to develop and advance isotopic approaches for characterizing fluid flow and chemical transport through the vadose zone to groundwater. Previous research has been concentrated on developing and comparing different isotopic systems (e.g., hydrogen, oxygen and strontium isotopes) for determining fluid infiltration rates and pathways in the vadose zone (e.g., Maher et al., 2003; DePaolo et al., 2004; Singleton et al., in press). The results demonstrate the unique advantage of studies of multiple isotopic systems for distinguishing short-term versus long-term processes. The focus of our current efforts is on using the isotopic compositions of different chemical phases (e.g., uranium, nitrate) to track their movement through the vadose zone. Preliminary results indicate that this will be a powerful tool for assessing environmental risks associated with vadose zone contamination.

\section{Research Progress and Implications (as of the first year of a 3 year renewal project)}

Strontium isotope variations in groundwater - We have measured the strontium isotope compositions $\left({ }^{87} \mathrm{Sr} /{ }^{86} \mathrm{Sr}\right)$ measured in groundwater samples from 273 wells in the unconfined aquifer below the Hanford Site. The data show large and regular isotopic variations that are a function of groundwater flow rates and drainage through the overlying vadose zone. Because the primary recharge areas for the aquifer are in Columbia River Basalts, the initial Sr isotopic composition of the groundwater is significantly different from sedimentary rocks that host most of the aquifer beneath the Hanford Site. As the groundwater traverses the site, chemical interaction with the sediments combined with water infiltrating through the vadose zone result in an increase in the ${ }^{87} \mathrm{Sr} /{ }^{86} \mathrm{Sr}$ of the groundwater from 0.707 to 0.712 . A steady-state model of strontium reactive transport and drainage based on this data yields an average natural drainage flux of $0-1.4 \mathrm{~mm} / \mathrm{yr}$ near the western margin of the Hanford Site and up to $30 \mathrm{~mm} / \mathrm{yr}$ in the center of the site. These estimates are entirely independent of any model for the vadose zone hydrology, yet are roughly in accord with the estimates based on soil grain size, vegetation cover and chloride mass balance. In contrast, the strontium isotope pattern deviates from the general pattern in areas where large amounts of water were dumped at the surface (e.g., the chemical processing plants in the central part of the site), reflecting flushing of dissolved and adsorbed strontium from the vadose zone into the groundwater (Singleton et al., in review).

Tracking Uranium Contamination in the Columbia River - We analyzed the uranium isotopic compositions of water samples from two traverses across the Columbia River. Upriver from the Hanford Site (near the Vernita Bridge), the samples had no detectable ${ }^{236} \mathrm{U}$ (a marker of processed uranium), normal ${ }^{238} \mathrm{U} /{ }^{235} \mathrm{U}$, and uniform ${ }^{234} \mathrm{U} /{ }^{238} \mathrm{U}$ (Figure 1). The second traverse is located downriver from the Hanford Site where the water supply for the town of Richland is pumped from the river. At this location, an island divides the river into western and eastern portions. West of the island, the measured ${ }^{236} \mathrm{U} /{ }^{238} \mathrm{U}$ is $34 \times 10^{-6}$ to $<0.02 \times 10^{-6}$, indicating a significant input of processed uranium. The ${ }^{238} \mathrm{U} /{ }^{235} \mathrm{U}$ correlated with the ${ }^{236} \mathrm{U} /{ }^{238} \mathrm{U}$, trending towards enriched ratios. These uranium isotopic compositions are consistent with the uranium 
isotopic compositions of a groundwater sample from the 300 Area (just north of Richland) and samples of two sampled seeps from the 300 Area shore. The compositions also project toward the model compositions of $2^{\text {nd }}$ cycle enriched uranium fuels. The samples with the highest ${ }^{236} \mathrm{U} /{ }^{238} \mathrm{U}$ have the highest $\mathrm{U}$ concentrations. For the most contaminated sample, a mass balance calculation indicates that $\sim 35 \%$ of the total uranium is derived from contamination. The results demonstrate that high precision $U$ isotope measurements provide sensitive detection of even small amounts of $U$ contamination, and can distinguish Hanford $U$ from other sources.
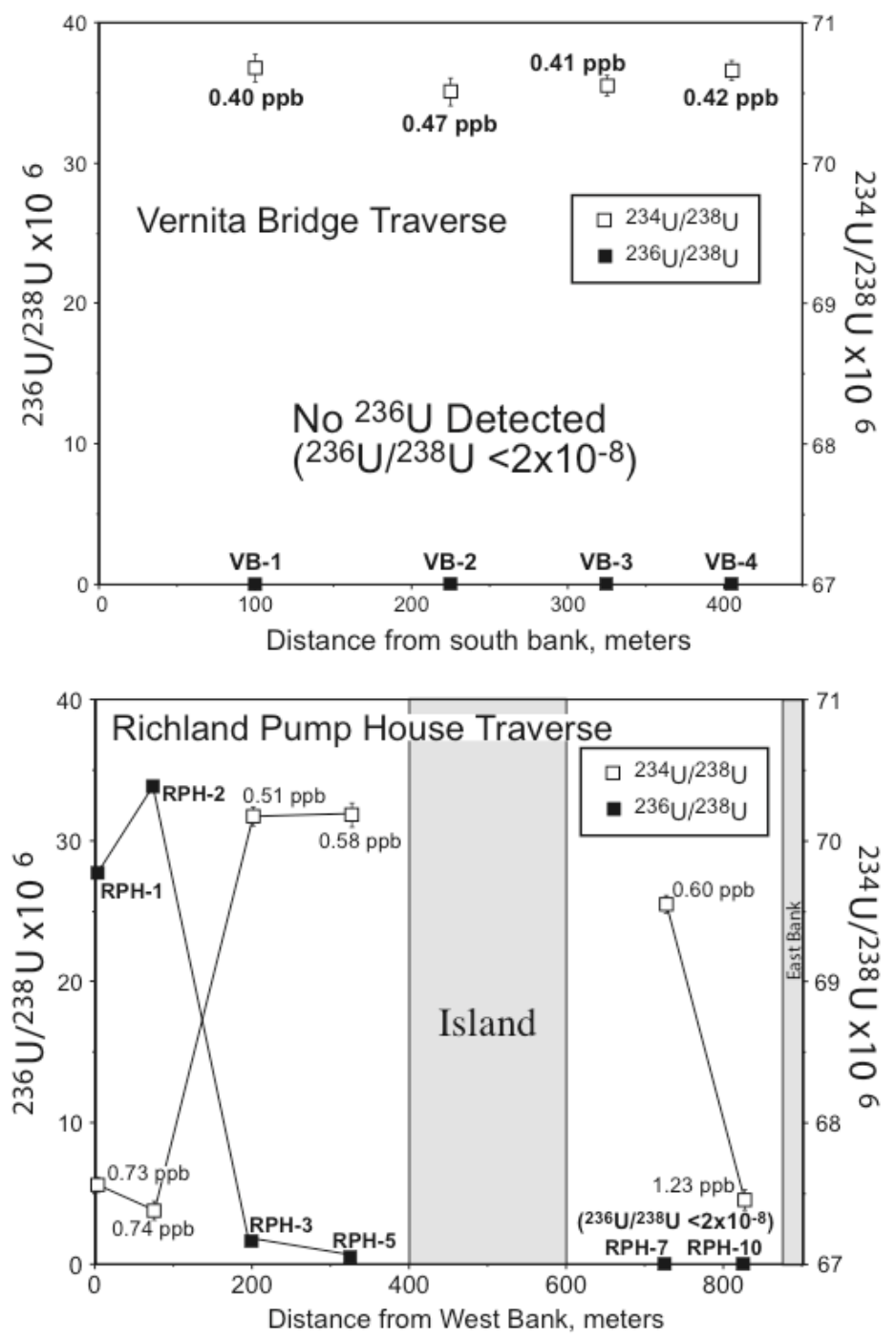

Figure 1. Uranium isotope data for water samples from two traverses across the Columbia River; one at the Vernita Bridge upriver from the Hanford Site and one at the Richland Pump House just downriver from the Hanford Site.

Isotope Fingerprinting of Groundwater Nitrate at Hanford - Using a novel, microbiologically-based method for analyzing $\delta^{15} \mathrm{~N}$ and $\delta^{18} \mathrm{O}$ of dissolved nitrate in water, we have been measuring the isotopic composition of groundwater and pore water extracts from vadose zone sediments from the Hanford Site for the purpose of determining the source of groundwater nitrate. To date, groundwater samples from 77 wells with nitrate concentrations 
from 1.5 to $763 \mathrm{mg} / \mathrm{L}$ have been analyzed. The isotopic composition of nitrate plumes in the 200 areas are consistent with a mixture of nitrate from soil processes and high $\delta^{18} \mathrm{O}$ nitrate characteristic of synthetic nitrate (e.g., nitric acid) or nitrate from the caliche layers present in the Hanford vadose zone. Elevated nitrate concentrations in outlying areas have isotopic compositions similar to natural, soil-derived nitrate. Nitrate associated with high-level radioactive contamination in the vadose zone has a unique nitrate isotopic composition $\left(\delta^{15} \mathrm{~N}\right.$ of 10 to $35 \%$ and $\delta^{18} \mathrm{O}$ of -5 to $5 \%$ ) that was likely imparted by the nitrate-ammonia redox chemistry used during plutonium recovery processing (Figure 2). So far, only a few wells located near tank farms (S-SX, T, and A-AX) have nitrate isotopic compositions consistent with the vadose zone contamination. Our preliminary data indicate that most of the elevated nitrate concentrations in Hanford groundwater resulted from natural nitrate flushed from the soil column during low-level wastewater disposal, rather than migration of vadose zone contamination.

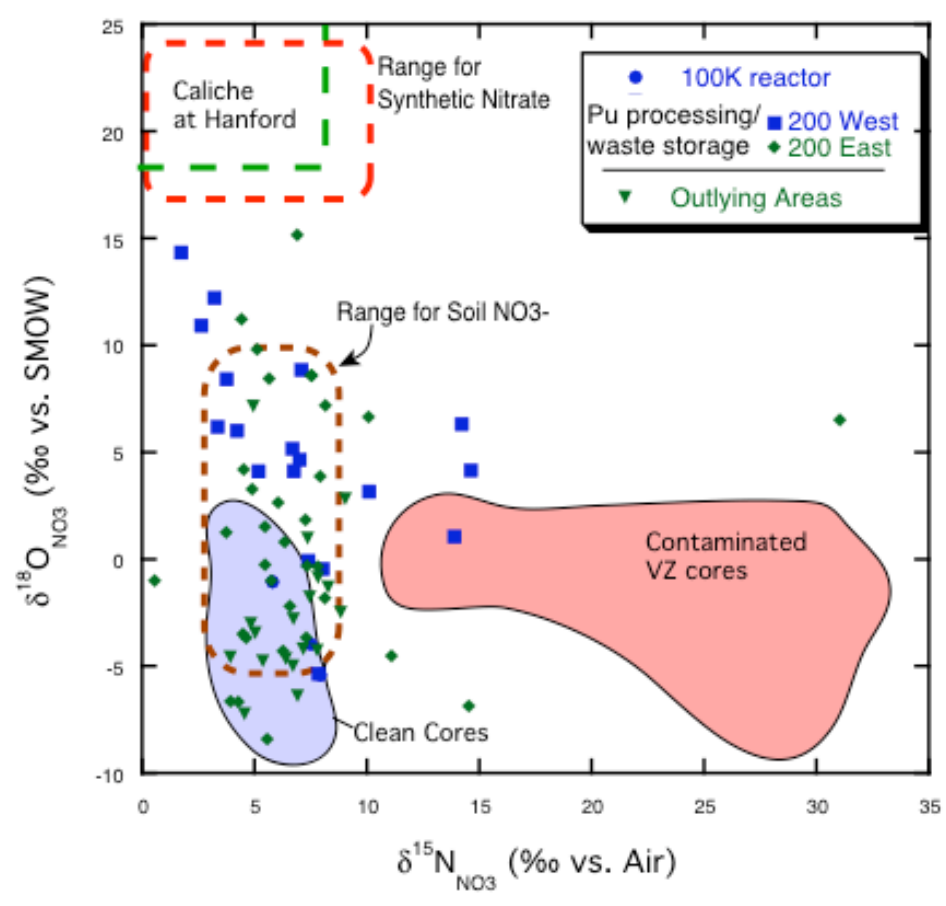

Figure 2. Nitrogen and oxygen isotope data for groundwater and vadose zone pore water from the Hanford Site. Also shown are typical ranges of nitrate isotope compositions for soil nitrate and synthetic nitrate.

$\delta \mathrm{D}$ and $\delta^{18} \mathrm{O}$ measurements of vadose zone pore water - In an ongoing effort to understand the effects of the coupled effects of infiltration and evaporation on the isotopic composition of vadose zone pore water, we have been analyzing the stable isotope compositions of water from large lysimeters (2-7 $\mathrm{m}$ deep sediment columns with drainage and access ports) at the Hanford Site (the VZ300N and Field Lysimeter Test Facility sites). The resulting data are used to constrain numerical models of isotope transport and fractionation in the vadose zone developed to be able to use stable isotope data to constrain infiltration rates (Singleton et al., in press).

\section{Planned Activities}


In addition to continuing work on the studies outlined above, we are planning the following activities for the coming fiscal year:

1. Groundwater Uranium Isotope Map - Natural variations in the ${ }^{234} U /{ }^{238} U$ of vadose zone pore water and ground water are caused by alpha recoil effects and are a function of factors including sediment weathering rates, grain size and fluid flow rates. This data can be used to determine risk factors associated with contaminant uranium.

2. Boron Isotopes in Groundwater - The isotopic composition of boron in water records past and present $\mathrm{pH}$ history. Given the extreme $\mathrm{pH}$ fluids produced by site activities, we anticipate that this will provide a valuable tool for tracing contamination. We have obtained the NIST Boron isotopic standard (SRM 951), and have made some test runs of B isotopic analyses using negative-ion techniques on our new Finnigan Triton thermal ionization mass spectrometer and plan to begin analyzing samples from Hanford this year.

3. ${ }^{100 N}{ }^{90} \mathrm{Sr}$ plume - During operation of the $\mathrm{N}$ reactor, hot cooling water $\left(\sim 90^{\circ} \mathrm{C}\right)$ containing ${ }^{90} \mathrm{Sr}$ was discharged to the ground. We are planning to use isotopic compositions $(\mathrm{H}, \mathrm{C}, \mathrm{O}$, $\mathrm{Sr}, \mathrm{U}$ ) of pore waters and secondary minerals (e.g., calcite, clay minerals) from the impacted area to study the mobility of strontium and uranium under elevated temperature conditions.

\section{Information Access}

\section{Peer-reviewed Articles Published in or Submitted to Scientific Journals}

1. Maher, K., D.J. DePaolo, M.E. Conrad, and R.J. Serne, 2003, Vadose zone infiltration rate at Hanford, Washington, inferred from Sr isotope measurements: Water Resources Res. 39, 1204.

2. Conrad, M.E. and D.J. DePaolo, 2004, Carbon isotopic evidence for biodegradation of organic contaminants in the shallow vadose zone of the Radioactive Waste Management Complex: Vadose Zone J. 3, 143-152.

3. DePaolo, D.J., M.E. Conrad, K. Maher and G.W. Gee, 2004, Oxygen and hydrogen isotopes in pore fluids from a 70m-thick vadose zone soil section at Hanford, Washington: Implications for recharge and horizontal fluid movement: Vadose Zone J. 3, 220-232.

4. Singleton, M.J., E.L. Sonnenthal, M.E. Conrad, D.J. DePaolo and G.W. Gee, in press, Multiphase reactive transport modeling of stable isotope fractionation of infiltrating unsaturated zone pore water and vapor using TOUGHREACT: Vadose Zone J.

5. Singleton, M.J., K. Maher, D.J. DePaolo, M.E. Conrad, and P.E. Dresel, in review, Determining flow, recharge, and vadose zone drainage in an unconfined aquifer from groundwater strontium isotope measurements, Pasco Basin, WA.

\section{Presentations at Scientific Meetings}

1. Singleton, M.J., Maher, K., DePaolo, D.J., Conrad, M.E., and Dresel, P.E., 2003, Sr isotope compositions of groundwater in the Hanford Site unconfined aquifer as a record of flow, recharge, and vadose zone infiltration. Geol. Soc. Am. Ann. Mtg, Abst. and Prog. 34 (7), 532.

2. Woods, K.N.; Singleton, Michael J., and Conrad, Mark. Application of a modified denitrifying bacteria method for analyzing groundwater and vadose zone pore water nitrate at the Hanford Site, WA, USA. Geol. Soc. Am. Ann. Mtg, Abst. and Prog. 34 (7), 405. 